\title{
Teorema Berbasis Aksioma Separasi dalam Ruang Topologi
}

\author{
Albert Ch. Soewongsono, Ariyanto, Jafaruddin \\ Jurusan Matematika Fakultas Sains dan Teknik Undana Kupang \\ Jalan Adisucipto Kampus Penfui Kupang NTT \\ Email: albert_soewongsono@yahoo.co.id
}

\begin{abstract}
ABSTRAK
Pada artikel ini dikaji karakteristik dan hubungan antara aksioma-aksioma separasi dalam ruang-ruang topologi yaitu, ruang $T_{1}$, ruang $T_{2}$ (Ruang Hausdorff), ruang $T_{3}$, ruang $T_{4}$, dan ruang metrik. Aksioma separasi adalah suatu aksioma yang digunakan untuk mengklasifikasikan ruang-ruang topologi berdasarkan distribusi himpunan terbukanya. Metode yang digunakan dalam kajian ini adalah dengan menggabungkan premis-premis dari aksioma separasi dalam ruang-ruang topologi sehingga dapat diperoleh teorema yang menghubungkan ruang-ruang topologi. Pada kajian ini, diperoleh hubungan antara ruang-ruang topologi tersebut yakni, setiap ruang $T_{4}$ adalah ruang $T_{3}$, setiap ruang $T_{3}$ adalah ruang $T_{2}$, setiap ruang $T_{2}$ adalah ruang $T_{1}$ tetapi tidak berlaku untuk pernyataan sebaliknya. Diperoleh juga bahwa, setiap ruang metrik memenuhi semua aksioma separasi dalam ruang $T_{1}, T_{2}, T_{3}$, dan $T_{4}$. Diskusi tentang aksioma separasi dalam ruang topologi masih terbuka dengan membandingkan aksioma separasi dari ruang-ruang topologi yang lebih kompleks seperti, ruang Tychonoff dan ruang Urysohn.
\end{abstract}

Kata kunci : Aksioma separasi, ruang topologi, ruang metrik, ruang $T_{1}$, ruang $T_{2}$, ruang $T_{3}$, ruang $T_{4}$.

\begin{abstract}
In this paper, examined characteristic and relationship between separation axioms in topological spaces which are, $T_{1}$ space, $T_{2}$ space (Hausdorff space), $T_{3}$ space, $T_{4}$ space, and metric space. Separation axioms are axioms that use to classified these topological spaces based on distribution of the open sets. The method that has been used in this paper is by combining premises of separation axiom in topological spaces so able to find theorems that connect these topological spaces. The results show there are relations between these topological spaces such as, every $T_{4}$ space is $T_{3}$ space, every $T_{3}$ space is $T_{2}$ space, every $T_{2}$ space is $T_{1}$ space but not the reverse statement. Also given that, every metric space fulfils all separation axioms in $T_{1}$ space, $T_{2}$ space, $T_{3}$ space, and $T_{4}$ space. The discussion about separation axiom in topological spaces is still open by comparing separation axiom in more complex topological spaces such as, Tychonoff space and Urysohn space.
\end{abstract}

Keywords : Separation axioms, topological space, metric space, $T_{1}$ space, $T_{2}$ space, $T_{3}$ space, $T_{4}$ space.

\section{Pendahuluan}

Pada matematika terdapat banyak cabang ilmu yang dipelajari. Salah satunya adalah matematika analisis dimana dipelajari konsep tentang sistem bilangan. Matematika analisis terbagi menjadi dua bagian yaitu, analisis real yang mempelajari konsep pada sistem bilangan real dan analisis kompleks yang mempelajari konsep pada sistem bilangan kompleks. Pada analisis real, beberapa konsep yang dipelajari antara lain, limit fungsi, derivatif, integral, dan lain-lain. Pada perkembangannnya dikenal analisis modern atau analisis abstrak. Topologi dan ruang topologi adalah salah satu cabang dari analisis ini (Apostol, 1974).

Banyak hal menarik yang dapat dipelajari dalam ruang topologi, salah satunya adalah tentang aksioma separasi dalam ruang-ruang topologi yang mengklasifikasikan ruang-ruang topologi berdasarkan distribusi himpunan terbuka (Lipschutz, 1983; Roy, 2013). Aksioma separasi yang memberikan ciri dari masing-masing ruang topologi.

Berdasarkan aksioma separasinya, dapat dicari hubungan antara ruang-ruang topologi yakni, ruang $T_{1}$, ruang $T_{2}$ (Ruang Hausdorff), ruang $T_{3}$, ruang $T_{4}$, dan ruang metrik. Untuk mendapatkan hubungan tersebut, prosedur penelitian yang dilakukan antara lain, pemaparan 
definisi ruang topologi dan ruang metrik, penjelasan aksioma-aksioma separasi dari masingmasing ruang topologi, dilanjutkan dengan elaborasi premis dari aksioma-aksioma separasi dalam ruang $T_{1}$, ruang $T_{2}$ (Ruang Hausdorff), ruang $T_{3}$, ruang $T_{4}$ sehingga, dapat diperoleh hubungan antara ruang $T_{1}$, ruang $T_{2}$ (Ruang Hausdorff), ruang $T_{3}$, ruang $T_{4}$, dan ruang metrik melalui penurunan teorema-teorema dan setelah diperoleh hubungan tersebut dapat dibentuk pengelompokkan ruang-ruang topologi dan ruang metrik dari yang mempunyai lingkup tersempit hingga yang mempunyai lingkup terluas..

Organisasi artikel ini pada bagian 2 menjelaskan definisi ruang topologi dan ruang metrik serta teorema-teorema yang diperlukan pada bagian 3 yang membahas hubungan antara ruang $T_{1}$, ruang $T_{2}$ (Ruang Hausdorff), ruang $T_{3}$, ruang $T_{4}$, dan ruang metrik.

\section{Ruang Topologi dan Ruang Metrik}

Pada bagian ini akan diberikan definisi pembentukan ruang topologi dan ruang metrik serta beberapa definisi dan teorema lain yang diperlukan dalam pembahasan pada bagian 3 .

\subsection{Ruang Topologi}

Konsep tentang topologi dan ruang topologi berawal dari pembahasan mengenai himpunan terbuka dalam $\mathfrak{R}$ dimana, dibahas mengenai titik dalam, titik batas, dan titik limit (Bartle, 1992). Beberapa sifat himpunan terbuka dalam sistem bilangan real $\mathfrak{R}$ adalah sebagai berikut : Misalkan $\tau$ adalah keluarga semua himpunan terbuka dalam $\mathfrak{R}$, maka $\tau$ memenuhi sifatsifat, (i) $\phi, \Re \in \tau$, (ii) $A_{\alpha} \in \tau, \forall \alpha \in I \Rightarrow \bigcup_{\alpha \in I} A_{\alpha} \in \tau$ dimana $I$ adalah himpunan indeks, dan (iii) $A, B \in \tau \Rightarrow A \cap B \in \tau$ (Lipschutz, 1983; Korner, 2014).

Pada perkembangannya, konsep tersebut dapat diabstraksikan menjadi tidak hanya didefinisikan dalam sistem bilangan real $\mathfrak{R}$ melainkan pada sebarang himpunan tidak kosong $X$ yang memenuhi beberapa sifat berikut.

Misalkan $X$ adalah sebarang himpunan tidak kosong. $\tau$ adalah keluarga himpunan bagian terbuka dari $X$ yang memenuhi sifat-sifat :

(i) $\phi, X \in \tau$

(ii) $A_{\alpha} \in \tau, \forall \alpha \in I \Rightarrow \bigcup_{\alpha \in I} A_{\alpha} \in \tau$

$I$ adalah himpunan indeks

(iii) $A, B \in \tau \Rightarrow A \cap B \in \tau$

maka, $\tau$ disebut topologi pada $X$ dan pasangan $(X, \tau)$ disebut sebagai ruang topologi (Lipschutz, 1983; Korner, 2014).

Definisi 2.1.1. Titik Dalam (Interior Point) pada Ruang Topologi

Diketahui $(X, \tau)$ adalah ruang topologi dan $A \subset X$. Titik $p$ disebut titik dalam (interior point) himpunan A bila ada $G_{p} \in \tau$ dan $G_{p} \subset A$ (Lipschutz, 1983).

\section{Definisi 2.1.2. Himpunan Terbuka}

Himpunan A dikatakan terbuka jika semua anggotanya adalah titik dalam (interior point) dari A (Soemantri, 2004).

Teorema 2.1.3

Setiap persekitaran adalah himpunan terbuka (Bartle, 1992).

Bukti. Diambil $a \in \mathfrak{R}$ dan $\varepsilon>0$. Akan ditunjukkan, $N_{\varepsilon}(a)=\{x \in \mathfrak{R}:|x-a|<\varepsilon\}$. Diambil 
sebarang titik $y \in N_{\varepsilon}(a)$. Selanjutnya, dibentuk $r=|y-a|$ dan jelas $r<\varepsilon$. Misalkan, $\delta=\varepsilon-r$ maka $\delta>0$. Dibuat persekitaran $N_{\delta}(y)$ dan diambil sebarang titik $z \in N_{\delta}(y)$ maka diperoleh, $|z-a| \leq|z-y|+|y-a|<\delta+r=\delta+(\varepsilon-\delta)=\varepsilon$ atau $|z-a|<\varepsilon$ yang berarti, $z \in N_{\varepsilon}(a)$. Jadi, jika $z \in N_{\delta}(y)$ maka $z \in N_{\varepsilon}(a)$ ekuivalen dengan $N_{\delta}(y) \subset N_{\varepsilon}(a)$. Sehingga, menurut definisi titik dalam (interior point), $y$ merupakan titik dalam $N_{\varepsilon}(a)$. Selanjutnya, karena $y$ diambil sebarang maka terbukti bahwa persekitaran $N_{\varepsilon}(a)$ merupakan himpunan terbuka.

\section{Definisi 2.1.4. Topologi Diskrit}

Misalkan X adalah suatu himpunan tidak kosong dan $\tau$ adalah himpunan kuasa dari $X$ maka, $\tau$ disebut topologi diskrit pada X (Lipschutz, 1983).

\subsection{Ruang Metrik}

Misalkan $X$ adalah sebarang himpunan tidak kosong.

(i) Fungsi $d: X \times X \rightarrow \mathfrak{R}$ yang memenuhi sifat-sifat:

$$
\begin{gathered}
\left(M_{1}\right) d(x, y) \geq 0, \forall x, y \in X \\
d(x, y)=0 \Leftrightarrow x=y, \\
\left(M_{2}\right) d(x, y)=d(y, x) \forall x, y \in X, \\
\left(M_{3}\right) d(x, y) \leq d(x, z)+d(z, y) \\
\forall x, y, z \in X .
\end{gathered}
$$

Disebut metrik atau jarak pada $X$.

(ii) Himpunan $X$ dilengkapi dengan suatu metrik $d$, dituliskan dengan $(X, d)$ disebut ruang metrik. Jika metriknya telah diketahui maka ruang metrik cukup ditulis $X$ saja.

(iii) Anggota ruang metrik $(X, d)$ disebut titik dan untuk setiap $x, y \in X$, bilangan non negatif $d(x, y)$ disebut jarak titik $x$ dengan titik $y$ (Darmawijaya, 1998; Ampang, 2011).

\section{Hasil dan Pembahasan}

Pada bagian ini akan dibahas mengenai aksioma separasi dalam ruang $T_{1}$, ruang $T_{2}$ (Ruang Hausdorff), ruang $T_{3}$, dan ruang $T_{4}$ sehingga, dapat diperoleh teorema yang menghubungkan ruang-ruang topologi tersebut dan ruang metrik. Sebelum itu, akan diberikan definisi yang menghubungkan ruang metrik dan ruang topologi sebagai berikut.

Misalkan $d$ adalah sebuah metrik pada himpunan tidak kosong $X$. Suatu topologi $\tau$ pada $X$ yang dihasilkan oleh kelas dari persekitaran dalam $X$ disebut topologi metrik atau topologi yang dihasilkan oleh metrik $d$. Selanjutnya, himpunan $X$ dengan topologi $\tau$ yang dihasilkan oleh metrik $d$ dinamakan, ruang metrik dan dinotasikan oleh $(X, d)$ (Lipschutz, 1983).

Dengan demikian, suatu ruang metrik adalah ruang topologi dimana topologinya dihasilkan oleh sebuah metrik. Oleh karena itu, semua konsep yang didefinisikan dalam ruang topologi juga didefinisikan dalam ruang metrik (Lipschutz, 1983; Darmawijaya, 1998). Akibatnya, dapat dicari hubungan antara ruang metrik dan ruang-ruang topologi lainnya dengan mengambil suatu topologi yang dihasilkan oleh suatu metrik. 


\subsection{Hubungan Aksioma Separasi dalam Ruang $T_{1}$ dan $T_{2}$}

\section{Definisi 3.1.1. Aksioma Separasi dalam Ruang $\boldsymbol{T}_{\mathbf{1}}$}

Ruang topologi $(X, \tau)$ disebut ruang $T_{1}$ jika untuk setiap $p, q \in X$ dengan $p \neq q$ terdapat $G, H \in \tau$ sedemikian sehingga $p \in G, p \notin H$ dan $q \notin H, q \notin G$.

\section{Teorema 3.1.2}

Ruang topologi $(X, \tau)$ merupakan ruang $T_{1}$ jika dan hanya jika untuk setiap $x \in X$, singleton $\{x\}$ adalah himpunan tertutup.

\section{Bukti.}

$(\Rightarrow)$ Diketahui bahwa $(X, \tau)$ merupakan ruang $T_{1}$.

Diambil sebarang $p \in X$ dan didefinisikan : $\{p\}$ adalah singleton.

Diambil sebarang $q \in\{p\}^{c} \subset X$ maka, $p \neq q$ sebab $\{p\}^{c} \cap p=\varnothing$. Karena $(X, \tau)$ adalah ruang $T_{1}$ maka terdapat $G, H \in \tau$ dengan $p \in G, p \notin H$ dan $q \in H, q \notin G$.

Jadi, $\exists H \in \tau$ dengan sifat $q \in H, p \notin H$ dan $H \subset\{p\}^{c}$.

Menurut Definisi 2.1.1 tentang titik dalam (interior point) pada himpunan terbuka maka, $q$ titik dalam (interior point) himpunan $\{p\}^{c}$. Karena $q$ diambil sebarang maka $\{p\}^{c}$ himpunan terbuka dan $\{p\}$ himpunan tertutup. Jadi, terbukti bahwa apabila $(X, \tau)$ merupakan ruang $T_{1}$ maka setiap singleton dari $X$ adalah tertutup.

$(\Leftarrow)$ Diketahui bahwa setiap singleton dari $X$ adalah himpunan tertutup.

Diambil sebarang $p, q \in X$ dan $p \neq q$. Dibentuk $\{p\}$ dan $\{q\}$ singleton akibatnya, $\{p\}$ dan $\{q\}$ tertutup. Selanjutnya didefinisikan : $G=\{p\}^{c}$ dan $H=\{q\}^{c}$ maka, $G$ dan $H$ terbuka.

Jelas bahwa, $p \in H, p \notin G$ dan $q \in G, q \notin H$.

Jadi, $\forall p, q \in X, \exists G, H \in \tau$ э $p \in H, p \notin G$ dan $q \in G, q \notin H$. Dari Definisi 3.1.1 tentang ruang $T_{1}$, terbukti bahwa $(X, \tau)$ merupakan ruang $T_{1}$.

Dari bukti syarat perlu dan syarat cukup maka, Teorema 3.1.2 terbukti.

Definisi 3.1.3. Aksioma Separasi dalam Ruang $\boldsymbol{T}_{\mathbf{2}}$

Ruang topologi $(X, \tau)$ merupakan ruang $T_{2}$ (Ruang Hausdorff) jika untuk setiap $p, q \in X$ dengan $p \neq q$, terdapat $G, H \in \tau$ э $p \in G, q \in H$ dan $G \cap H=\varnothing$.

\section{Teorema 3.1.4}

Setiap ruang $T_{2}$ (Ruang Hausdorff) merupakan ruang $T_{1}$.

Bukti. Misalkan $(X, \tau)$ adalah ruang topologi dan diketahui bahwa $(X, \tau)$ adalah ruang $T_{2}$. Ambil sebarang $p, q \in X$ dengan $p \neq q$. Karena $(X, \tau)$ adalah ruang $T_{2}$ maka, $\exists G, H$ $\in \tau \ni p \in G$ dan $q \in H, G \cap H=\varnothing$. Karena, $p \in G, q \in H$ dan $G \cap H=\varnothing$ maka, $p \notin H, q \notin G$.

Jadi, $\exists G, H \in \tau$ э $p \in G, p \notin H$ dan $q \in H, q \notin G$ sehingga, menurut Definisi 3.1.1 terbukti bahwa $(X, \tau)$ adalah ruang $T_{1}$.

\section{Akibat 3.1.5}

Tidak semua ruang $T_{1}$ adalah ruang $T_{2}$ (Ruang Hausdorff). 
Bukti. Andaikan pernyataan salah maka setiap ruang $T_{1}$ adalah ruang $T_{2}$. Ambil sebarang $p, q \in X$ dengan $p \neq q$ maka, $\exists G, H \in \tau \ni p \in G, q \in H$ dan $G \cap H=\varnothing$. Karena, $G, H \in \tau$ maka, $G$ dan $H$ adalah himpunan terbuka tidak berhingga sebab $G^{c}$ dan $H^{c}$ adalah himpunan tertutup dan berhingga. Karena, $G \cap H=\varnothing$ maka $G \cap H^{c} \neq \varnothing$ dan $G \subset H^{c}$. Pernyataan $G \subset H^{c}$ tidak mungkin terjadi sebab, $G$ tidak berhingga dan $H^{c}$ berhingga. Jadi, pengandaian salah dan pernyataan benar yakni, tidak semua ruang $T_{1}$ adalah ruang $T_{2}$.

\subsection{Hubungan Aksioma Separasi dalam Ruang $T_{2}$ dan $T_{3}$}

\section{Definisi 3.2.1: Aksioma Separasi dalam Ruang Regular}

Ruang topologi $(X, \tau)$ adalah ruang regular jika untuk setiap himpunan tertutup $F \subset X$ dan $p \in X, p \notin F$ maka, terdapat $G, H \in \tau, G \cap H=\varnothing$ э $F \subset G$ dan $p \in H$.

\section{Definisi 3.2.2: Aksioma Separasi dalam Ruang $\boldsymbol{T}_{3}$}

Ruang topologi $(X, \tau)$ merupakan ruang $T_{3}$ apabila $(X, \tau)$ adalah ruang regular dan memenuhi aksioma separasi dalam ruang $T_{1}$. Selanjutnya, ruang $T_{3}$ disebut juga sebagai ruang regular $T_{1}$.

\section{Teorema 3.2.3}

Setiap ruang $T_{3}$ adalah ruang $T_{2}$.

Bukti. Diketahui $(X, \tau)$ adalah ruang $T_{3}$. Diambil sebarang $p, q \in X, p \neq q$. Dibentuk singleton $\{p\}$ sedemikian sehingga $\{p\}$ tertutup. Jelas bahwa, $q \notin\{p\}$ sebab, $p \neq q$. Karena $(X, \tau)$ adalah ruang $T_{3}$ maka, $(X, \tau)$ adalah ruang regular sehingga, $\exists G, H \in \tau$ ,$G \cap H=\varnothing э\{p\} \subset G$ dan $q \in H$. Jelas bahwa, $p \in G$ sebab, $\{p\} \subset G$ dan $p \in\{p\}$.

Jadi, $\exists G, H \in \tau$ э $p \in G, q \in H$ dan $G \cap H=\varnothing$. Sehingga, menurut Definisi 3.1.3 tentang ruang $T_{2}$, terbukti bahwa $(X, \tau)$ merupakan ruang $T_{2}$.

\section{Sifat 3.2.4}

Tidak semua ruang regular merupakan ruang $T_{1}$.

Bukti. Akan ditunjukkan bahwa pernyataan benar dengan menggunakan sebuah contoh penyangkal berikut.

Pandang suatu ruang topologi $(X, \tau)$ dimana $X=\{a, b, c\}$ dan $\tau=\{\varnothing, X,\{a\},\{b, c\}\}$ adalah suatu topologi pada $X$. Akan ditunjukkan bahwa $(X, \tau)$ adalah ruang regular. Karena $\tau=\{\varnothing, X,\{a\},\{b, c\}\}$ maka, himpunan-himpunan tertutup pada $X$ adalah,

$X$ sebab, $X^{c}=\varnothing \in \tau$ terbuka.

$\varnothing$ sebab, $\varnothing^{c}=X \in \tau$ terbuka.

$\{a\}$ sebab, $\{a\}^{c}=\{b, c\} \in \tau$ terbuka.

$\{b, c\}$ sebab, $\{b, c\}^{c}=\{a\} \in \tau$ terbuka.

Dimana, himpunan-himpunan bagian tertutup dari $X$ dan memenuhi aksioma separasi dalam ruang regular yakni,

(i) Untuk $\varnothing \subset X$ berlaku,

$a \in X, a \notin \varnothing$ maka $\exists G=\{a\}, H=\{b, c\} \in \tau, G \cap H=\varnothing \ni \varnothing \subset H$ dan $a \in G$.

$b \in X, b \notin \varnothing$ maka $\exists G=\{a\}, H=\{b, c\} \in \tau, G \cap H=\varnothing \ni \varnothing \subset G$ dan $b \in H$. 
$c \in X, c \notin \varnothing$ maka $\exists G=\{a\}, H=\{b, c\} \in \tau, G \cap H=\varnothing \ni \varnothing \subset G$ dan $c \in H$.

Jadi, $\varnothing \subset X$ memenuhi aksioma separasi dalam ruang regular.

(ii) Untuk $\{a\} \subset X$ berlaku,

$b \in X, b \notin\{a\}$ maka $\exists G=\{a\}, H=\{b, c\} \in \tau, G \cap H=\varnothing \ni\{a\} \subset G$ dan $b \in H$.

$c \in X, c \notin\{a\}$ maka $\exists G=\{a\}, H=\{b, c\} \in \tau, G \cap H=\varnothing$ э $\{a\} \subset G$ dan $c \in H$.

Jadi, $\{a\} \subset X$ memenuhi aksioma separasi dalam ruang regular.

(iii) Untuk $\{b, c\} \subset X$ berlaku,

$a \in X, a \notin\{b, c\}$ maka $\exists G=\{a\}, H=\{b, c\} \in \tau, G \cap H=\varnothing \ni \varnothing \subset H$ dan $a \in G$.

Jadi, $\{b, c\} \subset X$ memenuhi aksioma separasi dalam ruang regular.

Dari (i), (ii) dan (iii) terbukti bahwa $(X, \tau)$ adalah ruang regular. Akan tetapi, $(X, \tau)$ bukan merupakan ruang $T_{1}$ sebab, terdapat sebuah singleton $\{b\}$ yang tidak tertutup. Terbukti bahwa tidak semua ruang regular merupakan ruang $T_{1}$.

Akibat 3.2.5. Syarat Cukup Suatu Ruang Regular Merupakan Ruang $\boldsymbol{T}_{\mathbf{1}}$

Jika suatu ruang regular $(X, \tau)$ dengan $\tau$ adalah suatu topologi diskrit maka $(X, \tau)$ merupakan ruang $T_{1}$.

Bukti. Diketahui $(X, \tau)$ adalah suatu regular dengan $\tau$ adalah suatu topologi diskrit yakni, $\tau=2^{x}, \forall x \in X$. Ambil sebarang $p, q \in X, p \neq q$ dan dibentuk singleton $\{p\},\{q\} \subset X$. Jelas bahwa, $\{p\}$ dan $\{q\}$ adalah himpunan tertutup sebab, $\{p\}^{c},\{q\}^{c} \in \tau=2^{x}$.

Dipilih, $F=\{p\} \subset X$ dan $q \in X, q \notin F=\{p\}$ sebab, $p \neq q$. Karena, $(X, \tau)$ adalah ruang regular maka, $\exists G, H \in \tau, G \cap H=\varnothing \ni F=\{p\} \subset G$ dan $q \in H$.

Jelas bahwa, $p \in G$ sebab, $p \in\{p\}$ dan $\{p\} \subset G$ tetapi, $p \notin H$ sebab, $G \cap H=\varnothing$. Berlaku juga $q \in H, q \notin G$ sebab, $G \cap H=\varnothing$.

Jadi, $\exists G, H \in \tau$ э $p \in G \backslash H$ dan $q \in H \backslash G$. Sehingga, menurut Definisi 3.1.1 tentang ruang $T_{1}$ terbukti bahwa, ruang regular $(X, \tau)$ juga merupakan ruang $T_{1}$.

\subsection{Hubungan Aksioma Separasi dalam Ruang $T_{3}$ dan $T_{4}$}

\section{Definisi 3.3.1. Aksioma Separasi dalam Ruang Normal}

Ruang topologi $(X, \tau)$ adalah ruang normal jika untuk setiap $F_{1}$ dan $F_{2}$ masing-masing adalah himpunan bagian tertutup dari $X$ yang saling lepas maka, $\exists G, H \in \tau, G \cap H=\varnothing$ э

$F_{1} \subset G$ dan $F_{2} \subset H$.

\section{Definisi 3.3.2. Aksioma Separasi dalam Ruang $\boldsymbol{T}_{4}$}

Ruang topologi $(X, \tau)$ adalah ruang $T_{4}$ apabila, $(X, \tau)$ merupakan ruang normal dan memenuhi aksioma separasi dalam ruang $T_{1}$. Selanjutnya, ruang $T_{4}$ dikenal juga sebagai ruang normal $T_{1}$.

Teorema 3.3.3

Setiap ruang $T_{4}$ adalah ruang $T_{3}$.

Bukti. Diketahui bahwa $(X, \tau)$ adalah ruang $T_{4}$. Diambil sebarang $F \subset X$ merupakan himpunan bagian tertutup dan $p \in X, p \notin F$.

Karena $(X, \tau)$ adalah ruang $T_{4}$ maka, $(X, \tau)$ merupakan ruang $T_{1}$. Dibentuk singleton $\{p\}$ himpunan tertutup. Jelas bahwa, $F \cap\{p\}=\varnothing$ sebab, $p \notin F$. Selanjutnya, karena $(X, \tau)$ 
adalah ruang $T_{4}$ maka, $(X, \tau)$ adalah ruang normal sehingga, $\exists G, H \in \tau, G \cap H=\varnothing \ni F \subset G$ dan $\{p\} \subset H$. Karena, $p \in\{p\}$ dan $\{p\} \subset H$ maka, $p \in H$.

Jadi, $\exists G, H \in \tau, G \cap H=\varnothing$ э $F \subset G$ dan $p \in H$. Sehingga, menurut Definisi 3.2.1, $(X, \tau)$ adalah ruang regular. Karena, $(X, \tau)$ adalah ruang regular dan ruang $T_{1}$ maka, berdasarkan Definisi 3.2.2 terbukti bahwa $(X, \tau)$ adalah ruang $T_{3}$.

\section{Sifat 3.3.4}

Tidak semua ruang normal adalah ruang $T_{1}$.

Bukti. Akan dibuktikan sifat tersebut dengan menggunakan sebuah contoh penyangkal berikut.

Misalkan $X=\{a, b, c\}$ dan $\tau=\{\varnothing, X,\{a\},\{b\},\{a, b\}\}$ adalah topologi pada $X$. Akan ditunjukkan bahwa $(X, \tau)$ merupakan ruang normal.

Karena $\tau=\{\varnothing, X,\{a\},\{b\},\{a, b\}\}$ maka, himpunan-himpunan tertutup dari $X$, adalah:

$\varnothing$ sebab, $\varnothing^{c}=X \in \tau$ himpunan terbuka.

$X$ sebab, $X^{c}=\varnothing \in \tau$ himpunan terbuka.

$\{b, c\}$ sebab, $\{b, c\}^{c}=\{a\} \in \tau$ himpunan terbuka.

$\{a, c\}$ sebab, $\{a, c\}^{c}=\{b\} \in \tau$ himpunan terbuka.

$\{c\}$ sebab, $\{c\}^{c}=\{a, b\} \in \tau$ himpunan terbuka.

Dari himpunan-himpunan tertutup di atas, dapat dilihat bahwa himpunan-himpunan tertutup yang saling lepas yaitu, $F_{1}=\varnothing$ dan $F_{2}=X$ atau $\{b, c\}$ atau $\{a, c\}$ atau $\{c\}$ э $\exists G=\varnothing$, $H=X \in \tau$ dimana, $G \cap H=\varnothing \cap X=\varnothing$ dan berlaku $F_{1}=\varnothing \subset G$ dan $F_{2} \subset H$. Jadi, terbukti bahwa $(X, \tau)$ di atas merupakan suatu ruang normal. Akan tetapi, $(X, \tau)$ di atas bukan merupakan ruang $T_{1}$ sebab, terdapat sebuah singleton $\{a\} \subset X$ yang tidak tertutup.

Terbukti bahwa tidak semua ruang normal adalah ruang $T_{1}$.

\section{Akibat 3.3.5. Syarat Cukup Suatu Ruang Normal Merupakan Ruang $\boldsymbol{T}_{1}$}

Jika $(X, \tau)$ merupakan suatu ruang normal dengan $\tau$ adalah suatu topologi diskrit maka, $(X, \tau)$ merupakan ruang $T_{1}$.

Bukti. Diketahui $(X, \tau)$ adalah suatu ruang normal dengan $\tau$ adalah suatu topologi diskrit yakni, $\tau=2^{x}, \forall x \in X$.

Diambil sebarang $p, q \in X$ dengan $p \neq q$. Dibentuk singleton $F_{1}=\{p\}, F_{2}=\{q\} \subset X$.

Jelas bahwa, $F_{1}=\{p\}$ dan $F_{2}=\{q\}$ himpunan tertutup sebab, $\{p\}^{c},\{q\}^{c} \in \tau=2^{x}$ dengan $F_{1} \cap F_{2}=\{p\} \cap\{q\}=\varnothing$. Karena, $(X, \tau)$ adalah ruang normal maka, $\exists G, H \in \tau, G \cap H=\varnothing$ э $F_{1}=\{p\} \subset G$ dan $F_{2}=\{q\} \subset H$.

Jelas bahwa, $p \in G$ sebab, $p \in\{p\}=F_{1}$ dan $F_{1}=\{p\} \subset G$ tetapi, $p \notin H$ sebab, $G \cap H=\varnothing$. Berlaku juga, $q \in H$ sebab, $q \in\{q\}=F_{2}$ dan $F_{2}=\{q\} \subset H$ tetapi, $q \notin G$ sebab, $G \cap H=\varnothing$. Jadi $\exists G, H \in \tau$ э $p \in G \backslash H$ dan $q \in H \backslash G$. Sehingga, menurut Definisi 3.1.1 tentang ruang $T_{1}$ terbukti bahwa, ruang normal $(X, \tau)$ merupakan ruang $T_{1}$. 


\subsection{Hasil Utama: Teorema Fundamental Separasi dalam Ruang Topologi}

Pada bagian ini, akan diberikan kumpulan teorema yang menghubungkan ruang metrik dengan ruang-ruang topologi yang dinamakan teorema fundamental separasi dalam ruang topologi.

\section{Teorema 3.4.1}

Setiap ruang metrik merupakan ruang $T_{1}$.

Bukti. Didefinisikan $(X, d)$ adalah ruang metrik. Diambil sebarang $p, q \in X$ dengan $p \neq q$. Karena $(X, d)$ adalah ruang metrik maka, $d(p, q)>0$. Selanjutnya, dibentuk persekitaran $N_{r}(p)$ dan $N_{r}(q)$ dengan $r=\frac{1}{2} d(p, q)$.

Akibatnya, diperoleh $N_{r}(p) \cap N_{r}(q)=\varnothing$. Menurut Teorema 2.1.3 $N_{r}(p)$ dan $N_{r}(q)$ adalah himpunan terbuka. Akibatnya, $N_{r}(p), N_{r}(q) \in \tau$. Jelas bahwa, $p \in N_{r}(p), p \notin N_{r}(q)$ dan $q \in N_{r}(q), q \notin N_{r}(p)$ sebab, $N_{r}(p) \cap N_{r}(q)=\varnothing$.

Jadi, $\exists N_{r}(p), N_{r}(q) \in \tau$ э $p \in N_{r}(p), p \notin N_{r}(q)$ dan $q \in N_{r}(q), q \notin N_{r}(p)$. Sehingga, terbukti bahwa $(X, d)$ adalah ruang $T_{1}$.

\section{Teorema 3.4.2.}

Setiap ruang metrik merupakan ruang $T_{2}$ (Ruang Hausdorff).

Bukti. Didefinisikan $(X, d)$ adalah ruang metrik. Selanjutnya, diambil sebarang $p, q \in X$ dengan $p \neq q$. Karena $(X, d)$ adalah ruang metrik maka, $d(p, q)>0$. Dibentuk persekitaran $N_{r}(p)$ dan $N_{r}(q)$ dengan, $r=\frac{1}{2} d(p, q)$. Akibatnya, diperoleh $N_{r}(p) \cap N_{r}(q)=\varnothing$. Dari Teorema 2.1.3, $N_{r}(p)$ dan $N_{r}(q)$ adalah himpunan terbuka. Akibatnya, $N_{r}(p), N_{r}(q) \in \tau$. Selanjutnya diperoleh, $p \in N_{r}(p), p \notin N_{r}(q)$ dan $q \in N_{r}(q), q \notin N_{r}(p)$ sebab $N_{r}(p) \cap$ $N_{r}(q)=\varnothing$.

Jadi, $\exists N_{r}(p), N_{r}(q) \in \tau$ э $p \in N_{r}(p), q \in N_{r}(q)$ dan $N_{r}(p) \cap N_{r}(q)=\varnothing$. Sehingga, terbukti bahwa $(X, d)$ merupakan ruang $T_{2}$.

\section{Teorema 3.4.3}

Setiap ruang metrik merupakan ruang $T_{3}$.

Bukti. Misalkan $\tau$ adalah suatu topologi pada $X$ oleh metrik atau jarak $d$. Ambil sebarang himpunan tertutup $F \subset X$ dan $p \in X, p \notin F$. Sehingga, $\exists r>0, \forall x \in F$ berlaku $d(x, p)>r$ >0. Dibentuk : $G=\bigcup_{x \in F} N_{r / 4}(x)$ dan $H=N_{r / 4}(p)$ dimana, menurut Teorema 2.1.3, $G$ dan $H$ adalah himpunan terbuka. Sehingga, $G, H \in \tau$ dan $G \cap H=\varnothing$. 


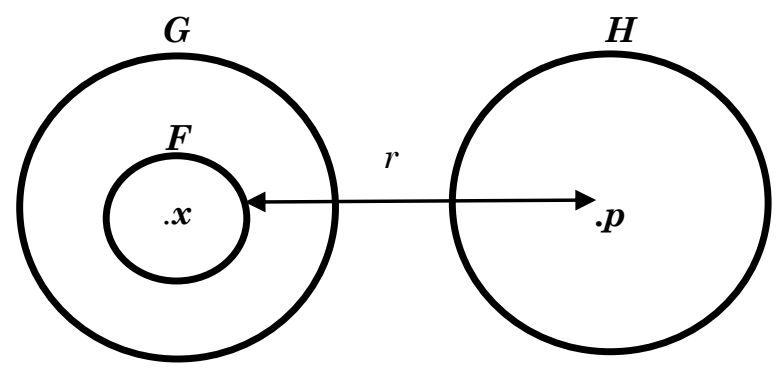

Gambar 1. Abstraksi pembentukan $G$ dan $H$

Jadi $\exists G, H \in \tau, G \cap H=\varnothing$ э $F \subset G$ dan $p \in H$. Menurut definisi ruang regular, dapat disimpulkan bahwa $(X, d)$ merupakan ruang regular.

Berdasarkan Teorema 3.4.1, telah ditunjukkan bahwa $(X, d)$ merupakan ruang $T_{1}$. Karena, $(X, d)$ memenuhi aksioma separasi dalam ruang regular dan ruang $T_{1}$ maka menurut definisi ruang $T_{3}$ terbukti bahwa $(X, d)$ merupakan ruang $T_{3}$.

\section{Teorema 3.4.4}

Setiap ruang metrik merupakan ruang $T_{4}$.

Bukti. Misalkan $\tau$ adalah topologi pada $X$ oleh metrik atau jarak $d$. Diambil sebarang himpunan-himpunan bagian tertutup $F_{1}, F_{2} \subset X$ dengan, $F_{1} \cap F_{2}=\varnothing$. Sehingga, $\exists r>0, \forall x$ $\in F_{1}, y \in F_{2}$ dengan, $d(x, y)>r>0$.

Dibentuk : $G=\bigcup_{x \in F_{1}} N_{r / 4}(x)$ dan $H=\bigcup_{y \in F_{2}} N_{r / 4}(y)$ dimana , dari Teorema 2.1.3 diperoleh, $G$ dan $H$ himpunan terbuka. Sehingga, $G, H \in \tau$ dan $G \cap H=\varnothing$.

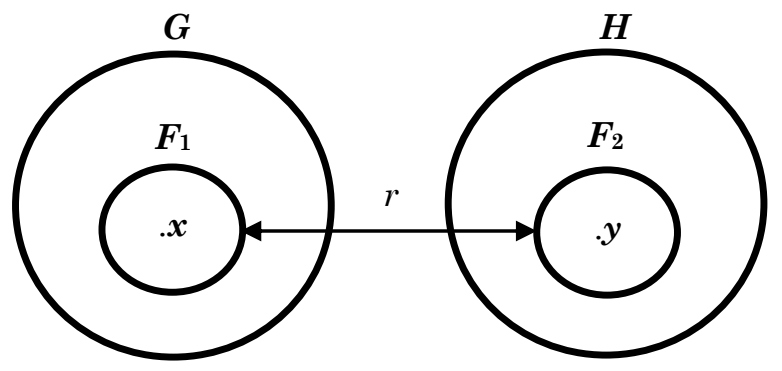

Gambar 2. Abstraksi pembentukan $G$ dan $H$

Jadi $\exists G, H \in \tau, G \cap H=\varnothing$ э $F_{1} \subset G$ dan $F_{2} \subset H$. Menurut definisi ruang normal, dapat disimpulkan bahwa $(X, d)$ adalah ruang normal. Selanjutnya, berdasarkan Teorema 3.4.1, telah ditunjukkan bahwa $(X, d)$ merupakan ruang $T_{1}$. Karena $(X, d)$ memenuhi aksioma separasi dalam ruang normal dan ruang $T_{1}$ maka terbukti bahwa $(X, d)$ merupakan ruang $T_{4}$.

Dari Teorema 3.4.1, Teorema 3.4.2, Teorema 3.4.3, dan Teorema 3.4.4 dapat dikatakan bahwa suatu ruang metrik memenuhi semua aksioma separasi dalam ruang-ruang topologi yakni, ruang $T_{1}$, ruang $T_{2}$, ruang $T_{3}$, dan ruang $T_{4}$. Sehingga, ruang metrik termuat dalam 
setiap ruang-ruang topologi tersebut sebagaimana ditunjukkan oleh gambar berikut yang menunjukkan hubungan antara ruang-ruang topologi dan ruang metrik.

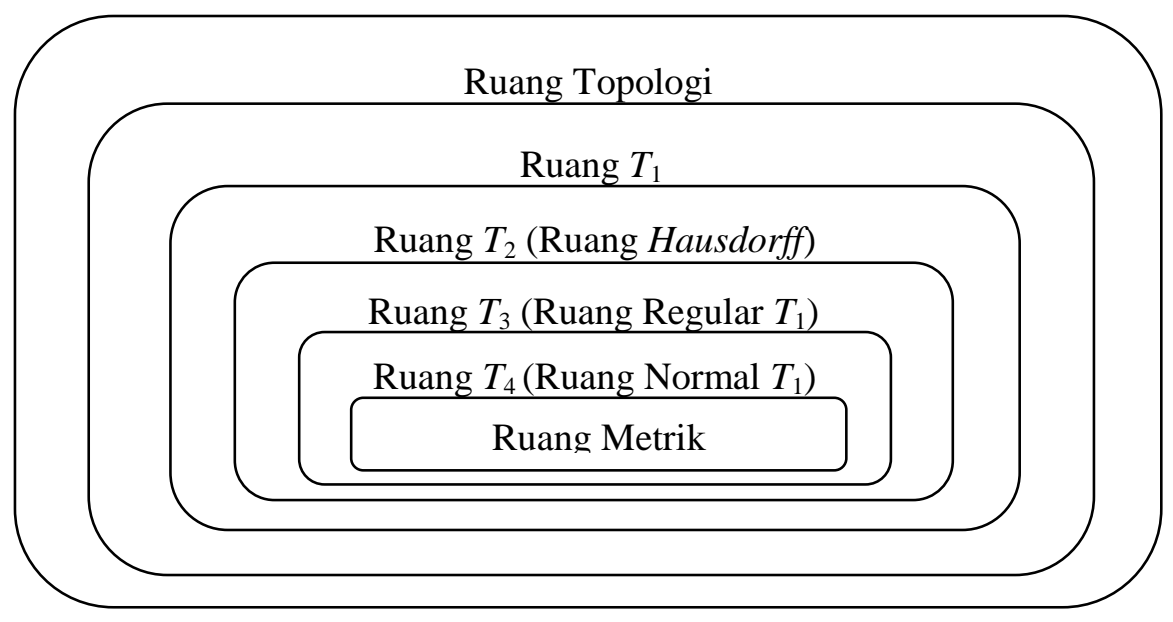

Gambar 3. Pengelompokkan ruang-ruang topologi

Dari Gambar 3 terlihat bahwa ruang metrik memiliki lingkup tersempit sebab, termuat di semua ruang-ruang topologi sedangkan, ruang topologi memiliki lingkup terluas sebab, memuat ruang-ruang topologi lain dan ruang metrik.

\section{Simpulan}

Dari hasil kajian ini diperoleh bahwa dengan menggabungkan premis dari aksiomaaksioma separasi dalam masing-masing ruang topologi tersebut, diperoleh beberapa sifat sebagai berikut. Setiap ruang $T_{2}$ (Ruang Hausdorff) merupakan ruang $T_{1}$. Selanjutnya, setiap ruang $T_{3}$ (Ruang Regular $T_{1}$ ) merupakan ruang $T_{2}$ (Ruang Hausdorff) dan setiap ruang $T_{4}$ (Ruang Normal $T_{1}$ ) merupakan ruang $T_{3}$ (Ruang Regular $T_{1}$ ) serta, setiap ruang metrik merupakan ruang-ruang topologi tersebut. Akan tetapi, sifat-sifat hubungan antara ruangruang topologi tersebut tidak berlaku untuk kebalikannya.

Dari hasil kajian ini, diperoleh juga suatu teorema fundamental separasi ruang topologi yang merupakan gabungan dari beberapa teorema yang menyimpulkan bahwa ruang metrik memenuhi semua aksioma separasi dalam ruang-ruang topologi yakni, ruang $T_{1}$, ruang $T_{2}$ (Ruang Hausdorff), ruang $T_{3}$, dan ruang $T_{4}$.

\section{Ucapan Terima Kasih}

Penulis utama dalam artikel ini menyampaikan terima kasih kepada yayasan VDMS yang telah memberikan beasiswa sejak tahun 2014 dan juga kepada UNDANA-DIKTI yang telah memberikan beasiswa Peningkatan Prestasi Akademik (PPA) tahun 2014 kepada penulis utama selama menempuh pendidikan strata 1 di UNDANA hingga terselesaikannya penulisan artikel ini.

\section{Daftar Pustaka}

1. Alhosaini, Asaas M.A. 2008. $t_{\gamma}$ - Open Sets and Separation Axioms. Journal of Kerbala University. 6(4): 1-7.

2. Ampang, Melyta. 2011. Kajian Ruang Koleksi Semua Fungsi Kontinu dari Interval Tertutup [a,b] ke Himpunan Bilangan Real (Skripsi). FST-UNDANA: Kupang.

3. Apostol, Tom M. 1974. Mathematical Analysis. 2nd ed. Addison-Wesley. ISBN 978-0-20100288-1.

4. Bartle.R.G, Sherbert.R.D. 1992. Introduction To Real Analysis. Jhon Wiley and Sons: New York. 
5. Darmawijaya, Soeparna. 1998. Pengantar Analisis. Percetakan UGM: Yogyakarta.

6. Korner. T.W. 2014. Metric and Topological Space. University of Cambridge: London.

7. Lipschutz, Seymour. 1983. General Topology: McGraw-Hill Book Company: New York.

8. Roy.Bishwambhar, Sen.Ritu, Noiri.Takashi. 2013. Separation Axioms On Topological SpacesA Unified Version. European Journal Of Pure And Applied Mathematics. 6(1): 44-52. 
Albert Ch. Soewongsono et all JMI Vol. 11 No. 2, Oktober 2015 pp. 85 - 96 